\title{
THE EFFECT OF COMIC STRIPS TECHNIQUE AND LEARNING MOTIVATION TOWARD THE STUDENTS' ACHIEVEMENT IN ENGLISH WRITING IN NURSING STUDENTS OF STIKES BULELENG
}

\author{
by: \\ Kadek Devy Marleni \\ Sekolah Tinggi llmu Kesehatan Buleleng \\ devy26marleny@gmail.com
}

\begin{abstract}
This study aimed at investigating whether the implementation of comic strips technique and the students' learning motivation gave a significant effect to the students' writing competency. The study was an experimental study by applying $2 \times 2$ factorial design. The population was 100 students of nursing programme which 2 classes were used as the samples which were assigned into two groups, i.e. experimental group and control group, by Cluster Random Sampling. The research data were collected through tests that were analysed by using Statistical Two-Way Anova and Tukey Test. The result shows that, first, there was a significant difference on the students' writing competency between the students who were taught by using comic strips technique and conventional writing technique, in which the students who were taught by using comic strips technique had higher writing competency than those students who were taught by using conventional technique. Second, there was a significant interactional effect on the students' writing competency between the technique applied and the students' learning motivation. Third, there was a significant difference on the students' writing competency between the students who had high learning motivation when they were taught by using comic strips technique and those who were taught by using conventional technique, in which the students who had high learning motivation taught by using comic strips technique had higher writing competency than those students who were taught by using conventional writing technique. Fourth, there was a significant difference between the students' writing competency of the students who had low learning motivation when they were taught by using comic strips technique and they were taught by using conventional technique, in which the students who had low learning motivation taught by using comic strip technique had higher writing competency than those students who were taught by using conventional writing technique.
\end{abstract}

Keywords: learning motivation, comic strips technique, writing competency.

\section{INTRODUCTION}

English is a very important language in the world. It is very important to spread and to develop science, technology, and education. By learning English, students can develop their ability and creativity in science and also in education; therefore, they can adapt technology from other countries. By learning this magnificent language starting from elementary school until higher school, the students are expected to be able to face the globalization era. Because of that English is used by the 
people all over the world as a means of communication. English is international language must be mastered by people not only students but also all the people in the world. It is because English really support their community and future in global area. Sometimes people think English is difficult to do and afraid to use it in their daily communication. Because of English is always ignored in the classroom and teaching learning process and communication for society.

In Bali English is so important to be learned for students in the school. Bali is one famous tourism object in Indonesia. Tourists are come to Bali to enjoy the beautiful panorama, mount, lake and also beach. Besides places, tourists also enjoy art, culture and tradition in Bali, because of English is beneficial to be learned. It makes easier communication with them and social interaction will be connected between each other. Besides, there are lots of international schools in Bali especially in Denpasar area. Most of international schools communicate using bilingual language but it dominated by English. International school not only famous in Denpasar area but also in Singaraja town. There are some international school exist in Singaraja. It is started from play group until junior high school. It means English has important role in education system. Besides English is also introduced in university and health school in Singaraja to support students in their communication in real life.

The aim of teaching English is to develop the students' oral or literal communicative ability. Oral or literal communicative ability means the students have concern with ability to understand and to express informations, opinions, ideas or fells; therefore, they can develop science and technology. Communicative ability means the students understand how to produce oral or literal texts. In this case, the four skills (listening, speaking, reading and writing) are used to perceive or to produce the discourse in social life or in literacy grade. According to Wells (1987), literacy grade includes performative (the students are able to read, write, listen, and speak by symbol used), functional (the students are able to use language to fulfill daily life need), informational (the students are able to access knowledge by ability of using language) and epidemic (the students are able to express knowledge into the target language). Besides aim of teaching English is to provide students with the knowledge that they are seeking. If a student is looking to become proficient in the English language, then the overall aim is to allow them to fully understand how to speak, listen, read and write, whilst at the same time understand the meaning behind the language.

Teaching English is not means how to speak but also how to write what we are speaking. It means that when students good in speaking skill it not means they are good in writing. Most of students fell writing skill is so difficult because the spelling and the meaning of words that they listen is not same with the literary. Writing is a progressive activity, which means that before writing, the writers have to think about what they are going to write. Students face difficulties when they are write their ideas into paragraph. Sometimes their ideas is not arise and it makes students frustration and afraid to write and the effect they are lazy to write anything. Actually writing 
activity helps students to explore creativity, imagination, independence, fluency, confidence and comprehension. Writing skill is specific abilities which help writers put their thoughts into words in a meaningful form and to mentally interact with the message. There are some goals of writing; the first goal is that writers are independent when they are able to write without much assistance. The second goal is that writers gain comprehensibility when they can write, so that, it can be read and understood by themselves and others. The third goal is that writers are fluent when they are able to write smoothly and easily as well as understandably. And the last goal is writers gain creativity when they can write their own ideas, not by copying what has already been written, so that, they can be read and understood (Hampton (1989)).

Raimes (1983) states that there are three reasons which make writing is very important to be taught to the students. The first reason is that while writing, the students have an opportunity in reinforcing their ability in grammatical structure and vocabulary in which the teachers have been working with in class. The second reason is that the students have a chance to be adventurous in language when they are writing. The last reason is the students become involved in the language with their readers. Furthermore, Raimes also states that teaching writing can help the students improve their basic ability in constructing good sentences and organizing them into a paragraph. Based on Hampton and Raimes' statements it can said that writing skill is so important to be taught to the student to helps them in their society and communication. Besides writing skill motivation in learning is also has important role in learning English. Motivation is an important factor that affects the students' achievement in studying English. One student is different from others because of the fact that their motivation is also different from others. It should be realized that every student is different each other, consequently he/ she has different motivation. There are two kinds of motivation, namely: intrinsic and extrinsic motivation. Intrinsic motivation occurs when a student wants to do something because it gives her or him happiness or it is important to do, while extrinsic motivation occurs when a student is forced to do something or because of a certain reason. The kind of motivation is support students to push themselves to write and learn English in good way and right purpose. However in real situation in the classroom are still students have difficulties in writing. They said that writing is so difficult to do not only in English lesson but also for some lesson which related writing skill. They do not know what are they should write and how to write it. They are afraid to do mistake when they are writing and pour their ideas into sentences and paragraph. Writing skill is not only taught in senior high school but also in higher school like university and institute in Bali. One of them is institute health and sciences Buleleng in Singaraja. English as one general lesson should be taught in midwifery and nursing programme. English has important role in curriculum in this institute. Students should have practice in the hospital around Singaraja and Denpasar, not only in the government hospital but also in 
international hospital. Because of that students should know and mastery English in good way. Besides there is implementation of English day in this institute and also there are exchange students to other country like Thailand, Filipina, and Japan. So English should be taught effectively in each grade and programme. In fact there are so many difficulties face by students when they are study English, especially in writing skill. They are so afraid to ask to write although it is about their self. They always lazy to write because they think writing is bored activity to do. They only copy paste from internet and put their name on the paper. They have no ideas and creativity in writing. There is no effort to push themselves to have good written task. Based on the phenomena in the classroom and students' difficulties the writer offer one technique to help them in writing activity will be more interesting.

One of the techniques that could be applied in teaching writing is comic strips technique. Comics are a series of pictures contain image and balloons to write the story (Mc.Cloud:1993:4). Comics are fun to be introduced to the students. It is because by reading a comic, the students will not be bored to read because a comic contains pictures and images. The colorful comics will make the student enjoy reading it. Comics can also motivate the students to write, because by seeing pictures or images in the comics, the students' ideas will occur and give a lot of inspirations for them. By reading comics, the students will have ideas to write effectively. In this case, comic strip can help the students improve and develop the students' ideas and their motivation in writing. The students can build and develop their ideas easily by interpreting pictures in the comic. They ordered be helped to write in chronological based on what they have read and seen in the pictures of the comic. There are some procedures that must be done by the teacher when they are using this technique (Megan: 2004), the first is selecting appropriate comic strips that is relevant to the students' level. The second is asking the students to read the comic strips and look for the specific events that happen in the story. The third is asking the students to identify the structures and the last is asking the students to write by using their own words. Based on the problems above, it can be formulated as follows: 1) is there any significant difference on the students' achievement in English writing between the students taught by using comic strip technique and conventional technique? 2) is there any interactional effect between the teaching techniques applied and the student's learning motivation toward their achievement in English writing? 3) is there any significant difference on the achievement in English writing of the students who have high learning motivation between those students taught by using comic strip and conventional technique? 4) is there any significant difference on the achievement in English writing of the students who have low learning motivation between those students taught by using comic strip and conventional technique?

The purpose of this study can be formulated as follows: 1) to investigate the difference between the students taught by using comic strip and conventional technique on their achievement in English writing. 2) to investigate the interactional 
effect between the strategies applied and the student's learning motivation on their achievement in English writing. 3) to investigate the difference between the students who have high learning motivation taught by using comic strips and conventional technique on their achievement in English writing. 4) to investigate the difference between the students who have low learning motivation taught by using comic strips and conventional technique on their achievement in English writing.

\section{DISCUSSION}

\subsection{The Difference Achievement in} English Writing between the Students Taught by Using Comic Strip and Conventional Technique

Based on the result of hypothesis testing, it was found out that the first hypothesis; there is a significant difference in the English writing skill between the students taught by using Comic Strip Technique and the students taught by using conventional technique. It was clearly seen from the finding which showed in its value probability. If the probability value was lower than 0.05 , Ho was rejected or $\mathrm{H} 1$ was received. And from the output, it was known that the probability value is 0.033 , which was lower than 0.05 . It means that there was a significant difference in writing skill between the students taught by using comic strip and those students taught by using conventional technique.

The mean score gained from two groups, the experimental group treated by using Comic Strip Technique and the control group treated by using conventional technique also indicated that the teaching technique implemented affected the students' achievement in writing. From the result of the descriptive analysis, it was known that the mean score of the students taught by using comic strip technique was 86.37; meanwhile the mean score of the students taught by using conventional technique was 84.3. It means that the students' writing skill taught by using comic strip technique was higher than those students taught by using conventional technique. Therefore, it could be concluded that the application of comic strip technique affected better than conventional technique on the students' writing skill.

This finding actually supports the previous studies on the effect of Comic strip technique on the students' English writing achievement. Csabay (2004) taught in language classes in Hungary by implementing comic strips technique. He found that comic strips technique brought cheerful atmosphere into the class. It could arouse students' interest and increase their motivation. It also could get the students' critical thinking of what they were going to write about the pictures word format given. Christophe Dony (2009) implemented comic strips technique to teach writing. By using comics, it was easier for his students to understand the material and they become interesting in writing. Parwasih (2009) held a research on writing narrative by using colored comic strips technique for the students of SMPN 2 Singaraja. It was found that the students who had been thought by using colored comic strips technique could write better sentences in terms of grammar, spelling, and punctuation.

The result of this study is also in line with McCloud (1993:4). He states that 
comic strip is written paper about a series of action, which is identified by a number of pictures and conversation among the characters written in a word balloon. The pictures in the comic book control the reader's interpretation of the words. The picture forces the reader to see what the writer wants him/ her to see. Action lines and dialogue balloons allow the reader to hear the messages in their heads, thus inviting the reader into the make believe world of comic books. Therefore, there are some advantages for the students in reading comics in English. Practitioners who have used comic strips technique to teach their students have stated that comic strips are helpful for motivation, have increased individual participation and have aroused unusual interest.

\subsection{The Interactional Effect between Teaching Techniques Applied and Learning Motivation upon the Students' Achievement in English Writing}

Based on the result of the hypothesis testing, it was found that, there was an interactional effect between the teaching techniques applied (comic strip and conventional technique) and the students' learning motivation on the students' writing skill was accepted. Ho was rejected or $\mathrm{H} 1$ was received if the probability value was lower than 0.05 . From the output, it was known that the probability value is 0.005 , which is lower than 0.05 . It means that, there was an interactional effect between the teaching techniques applied (comic strip and conventional technique) and the level of the students' learning motivation (high and low levels) on the students' writing skill.
Based on the hypothesis above, it could be concluded that the application of comic strips technique could give more opportunity for the students to practice writing skill and could increase students' motivation in writing English for both high and low learning motivation of the students. However, the application of the teaching techniques was responded more positively by the students who have high learning motivation. The students' positive responses could be seen from the students' involvement in the classroom. The result of the test showed that there was a significant different between high learning motivation students taught by using comic strip technique and conventional technique. The students' writing skill taught by using comic strips was higher than those students who were taught by using conventional technique. (argumentation)

Beside the technique applied by the teacher only, the students' success in learning is also influenced by their motivation in learning. The result of the study is in line with McClelland. He states that high learning motivation students tend to get more raises and are promoted faster because they are constantly trying to think of better ways doing things. While, low learning motivation students tend to avoid risk or hard task, do not have high responsibility of a certain task and do not evaluate the result, McClelland (2010). 
2.3 The Difference Achievement in English Writing of the Students who Have High Learning Motivation between the students Taught by Using Comic Strip Technique and Conventional Technique

Based on the result of the hypothesis testing, it was found that, there was a significant difference in the achievement of the students who have high learning motivation between the students who were taught by using comic strips technique and those students who were taught by using conventional technique in English writing was accepted. Based on the research finding's result, it showed that if $Q$ counted is higher than $Q$ critical value, it means that $\mathrm{Ho}$ is rejected or $\mathrm{H} 1$ is received. The result of the calculation shows that the value of $\mathrm{Q}$ counted is 3.02; meanwhile $\mathrm{Q}$ critical value is 2.83 . It means that $Q$ counted is higher than $Q$ critical value. Therefore, it could be concluded that there is a significant difference in their writing skill between the students taught by using comic strip technique and those students taught by using conventional technique.

The descriptive statistic analysis indicated that the mean score of the writing competency of the high learning motivation students taught by using comic strips technique is 91 . It is higher than the mean score of the students who have high learning motivation taught by using conventional technique (88.6). Therefore, it could be concluded that the application of comic strip technique affected better than conventional technique on the students' writing skill of the students who have high learning motivation.
The result of this study also supports the finding of McClelland (2010). He states that, there was a high correlation between achievement motivation students and final grade for junior high school students. In similar study, Chou in Tsailing (2002) proved that there was a very significant correlation among the high students' achievement motivation and English achievement. The students who had high achievement motivation got better achievement in English subject.

\subsection{The Difference Achievement in} English Writing of the Students who Have Low Learning Motivation between the students Taught by Using Comic Strip Technique and Conventional Technique

Based on the result of hypothesis testing, it was found out that, there was no a significant difference in the achievement of the students who have low learning motivation between the students who were taught by using comic strips technique and those students who were taught by using conventional technique in English writing was accepted. Based on the result of the analysis, it was discovered $\mathrm{Ho}$ is rejected or $\mathrm{H} 1$ is received if $\mathrm{Q}$ counted is higher than $Q$ critical value. The result of the calculation shows that the value of $\mathrm{Q}$ counted is 2.85; meanwhile $\mathrm{Q}$ critical value is 2.83 . It means that, there is a significant difference in writing skill between the students taught by using comic strip technique and those students taught by using conventional technique. The result of the descriptive statistic also showed the mean scores of each group. The mean score of the low learning motivation students who were taught by using comic strips was 81.73 and the low 
learning motivation students who were taught by using conventional technique was 56.73. Therefore, it could be concluded that the application of comic strip technique affected better than conventional technique on the students' writing skill of the students who have low learning motivation.

The result of this study is in line with the theories stated by some experts. Marhaeni (2005) states low achievement motivation students like statistic condition in which they fell secure and comfortable because they are not ready to receive new things and tend to consider those feedback indicates their weakness. Furthermore, McClelland (2010:3) states that the students who have low motivation would have more effort and exercises to make their achievement better. They just submit their works without caring the result. Students with low achievement motivation concern more about the environment. They want to know how people fell about themselves rather than how well they are doing.

\subsection{The students' Responses toward the Implementation of Comic Strips and Conventional Learning Technique in the Classroom}

It has been mentioned previously that this research aimed to investigate the effect of Comic Strip and leaning English motivation on the writing achievement of students. The result showed that there was a significant difference on the writing achievement of students who were taught by Comic strips and the writing achievement of those who were taught by conventional technique.

As it was observed from the instructional process, it was found out that Comic Strip technique gave positive respond toward the students both who have high and low learning motivation. Comic Strips could not only improve their writing skill but also their motivation in writing. The result of observation during teaching learning process showed that at the first time of the implementation of this technique some students seemed to be confused with this technique. It is because they were suspicious of what task they were to be assignment to. The researcher explained that pictures would help them in writing. The students seemed to give attention to the pictures and connected it to the others. And finally they understood all the steps. Firstly, they read the story, after that they found out the structure, and the last they started to write a story. Based on students' opinion to the implementation of Comic Strips, some students stated that it was easier for them to find an idea by the pictures given. They helped by the pictures and it guided the students to write the story. For the next session, it was observed that the students seemed like more active and participated seriously with their writing. The students who have high learning motivation help the low ones. The students had shared more chance to appreciate differences and share individual participation. It was observed that the low achievement motivation students sometimes switched into Indonesian during discussion session. At the last session, it was observed that all students seemed enjoy to the activities. In conventional technique, it showed that some students who have high learning motivation were serious in writing class. They wrote correctly and made good sentences. Their writing was good in order and easy to read. The low 
learning motivation students were often not ready in writing. It might be caused by they were lack of vocabularies and ideas.

Based on the result of the observation from the instructional process, the researcher asked some questions to high achievement motivation and low achievement motivation students of both experimental classes. First, whether the students had problems in writing English or not. Both high and low achievement students stated that they had problems in writing English. They felt unconfident when they were asked to write. They were also afraid of writing because they had limited vocabularies and they were afraid of making mistakes in their writing. Second, whether the technique applied by the teacher could improve the students' writing skill or not. The students of high learning motivation stated that the techniques gave them chance to practice, learn and develop their skill in writing, but low learning motivation students stated that the technique was difficult to do. Third, whether the technique applied by the teacher could improve the students' motivation in learning English or not. The result showed that all the students of high learning motivation stated that Comic strips technique could improve their motivation in learning English. By the pictures given, the students were easy to understand the story and to arrange sentences. The pictures also helped and guided them to find out ideas. While some students who have low learning motivation stated that this technique was very difficult to do.

It could be concluded that Comic Strips techniques gave more opportunities for the students to practice writing and could increase students' motivation in writing English for both high and low learning motivation students.

\section{Implication}

Regarding moderator variable, the writing achievement of the students who had high learning motivation, who were taught by comic strips technique was higher than who were taught by conventional technique. This finding proved that comic strips technique could increase English writing achievement of nursing in institute health and sciences. Comic strips technique was very effective, because by using this technique, the students could learn, motivate and creative in writing.

The basic concepts of Comic Strips Technique enable the students to develop according to their ability and their talent. Steps in Comic Strips can give good chance for the students to increase their skills and ability in English writing. Statistical analysis showed that conventional technique could not affect positively toward the writing achievement of nursing in institute health and sciences. Conventional technique did not give chance to the students to developed their ideas and creativity in writing. This technique places the students as an object of learning or as a receiver of information passively not as a part of learning.

Based on the finding's result, it showed that comic strips technique is a suitable technique for the students who had high learning motivation. On the other hand, for the students who had low learning motivation if they were taught by conventional technique tends to be 
increasing if its compared with they were taught by comic strips technique, because they regarded that comic strips technique is a complicating technique, so they felt they should learn again and again to understand well, while conventional technique is usual for them, they felt that conventional technique is not complicated. For the students who had low learning motivation preferred usual situation which makes them pleasant and comfortable. They are lack of readiness to achieve critic or suggestion because they regard that feedback that is given for them show their weakness, and at last they decrease their learning motivation.

The result of this study shows that the students treated by using comic strips technique have a significantly better achievement that the students treated by using conventional technique. Having known that the implementation of comic strips technique affected differently to the students writing skill, especially for high learning motivation students, it is then strongly implied that teachers should reconsider the implementation of comic strip technique in teaching writing.

The observation in the classroom showed that the students become more confident to write, the high motivation students helped the low motivation students. It showed that when the low learning motivation students matched with the teaching technique applied by the teacher, the students' motivation and performance in learning would increase.

It can be concluded that comic strips technique can increase writing achievement if it is used for the students who have high learning motivation. For the students who have low learning motivation, comic strips can also increase writing achievement provided they are made sure to be active to try the new technique. This effort can be done by building their self confidence that comic strips technique is not complicated but it can help the students to increase their writing achievement. If they are used to learning by cooperative learning, they will be able to increase their learning motivation while they will be able to increase their writing achievement. All the above discussion about English writing achievement, comic strips technique, conventional technique and learning motivation have explained that there is interaction among them.

\section{CONCLUSION}

Based on data analysis the result of this study as follow:

1. From the result of the descriptive analysis, it was known the mean score of the students taught by using comic strip technique was 86.37; meanwhile the mean score of the students taught by using conventional writing technique was 84.3. It means that, the students' writing skill taught by using comic strip technique was higher than those students taught by using conventional technique. Therefore, it could be concluded that the application of comic strip technique affected better than conventional technique on the students' writing skill.

2. This research hypothesis was answered by looking at the value of probability (Sig) of $\mathrm{tm}^{*} \mathrm{ml}$ (teaching method*learning level). If the probability value was lower than 0.05 , Ho was rejected or $\mathrm{H} 1$ was received. From the output, it was known that the probability value was 0.005 . It was 
lower than 0.05. It means that, there was an interactional effect between the teaching techniques applied (comic strip and conventional technique) and the students' learning motivation level (high and low levels) on the students' writing skill. Because there is an interactional effect between the teaching techniques applied and the students' learning motivation level on the students' writing competency, the data were then continued to be analyzed by using Tukey test to know the effect of interaction.

3. The result of the calculation shows that the value of $Q$ counted was 3.02; meanwhile $\mathrm{Q}$ critical value was 2.83 . $\mathrm{Ho}$ is rejected or $\mathrm{H} 1$ is received if $\mathrm{Q}$ counted is higher than $Q$ critical value. From the result of the calculation, $Q$ counted is higher than $Q$ critical value. It means that, there is a significant difference in writing skill between the students taught by using comic strip technique and those students taught by using conventional technique. To know which group is better, it can be seen from the mean of both groups. The mean score of students who have high learning motivation taught by using comic strip technique was 91. It is higher than mean score of the students who have high learning motivation taught by using conventional technique (88.6). Therefore, it could be concluded that the application of comic strip technique affected better than conventional technique on the students' writing skill of the students who have high learning motivation.

4. The result of the calculation shows that the value of $\mathrm{Q}$ counted was 2.85; meanwhile $\mathrm{Q}$ critical value was 2.83 .
Ho is rejected or $\mathrm{H} 1$ is received if $\mathrm{Q}$ counted is higher than $Q$ critical value. From the result of the calculation, it was found that $Q$ counted is higher than $\mathrm{Q}$ critical value. It means that, there is a significant difference in writing skill between the students taught by using comic strip technique and those students taught by using conventional technique. To know which group is better, it could be seen from the mean scores of both groups. The mean score of students who have low learning motivation taught by using comic strips technique was 81.73. It was higher than the mean score of the students who have low learning motivation taught by using conventional technique (56.73). So, it can be concluded that, the application of comic strip technique affected better than conventional technique on the students' writing skill of the students who have low learning motivation.

Based on the discussion explained in the previous chapter, it could be concluded that:

1. There was a significant difference on the achievement in English writing between the students who were taught by using comic strip technique and technique.

2. There was an interactional effect between the teaching techniques applied and the student's learning motivation toward the students' achievement in English writing.

3. There was a significant difference on the achievement in English writing of the students who have high learning motivation between the students who 
were taught by using comic strip technique and conventional technique.

4. There was a significant difference on the achievement in English writing of the students who have low learning motivation between the students who were taught by using comic strip technique and conventional technique.

\section{REFERENCES}

Csabay, Noémi. 2004. Using Comic Strips in Language Classes. Budapest, Hungary. http://eca.state.gov/for um/vols/vol44/no1/p24.htm

Dony, Christophe. 2009. How to use comics in the ESL classroom. Le Journal de BabeLg 27. ISSN 20311176, e-ISSN 2031-1168.

Marhaeni, A.A.IN. Developing Authentic Assessment For English Language Teaching . Paper, disajikan pada seminar " A Workshop for English Teachers in Bali, " Conducted by The English Education Students Association of Ganesha University of Education in April, 17th 2008 di Singaraja.

McClelland, D. 2010. Achievement Motivation. Available at File.C/ users/documents/ac.motivation. Mc Clelland.html.retrievd January 15, 2010.

McCloud, Scot. 1993. Understanding Comics by Harper Collins Publishers

Parwasih, Ni Kadek.2009. The Use Of "Colored Comic Strips Technique" To Improve Students Competency In Writing a Narative Paragraph in Class VIIIA Of SMP Negeri 2 Singaraja in The Academic Year 2008/2009. Skripsi (tidak diterbitkan). Jurusan Pendidikan Bahasa dan Sastra, Undiksaha Singaraja.

Raimes, A. (1983) Techniques in Teaching Writing. Oxford: Oxford University Press. 